\title{
Rediscovering Lucretius in the Renaissance: His Impact on Modern Western Thought
}

\author{
Ioannis Deligiannis \\ Democritus University of Thrace \\ Department of Greek Philology \\ University Campus \\ 69100 Komotini \\ inteligi@helit.duth.gr
}

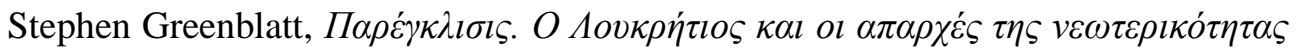

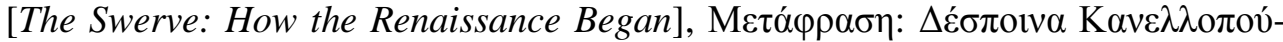

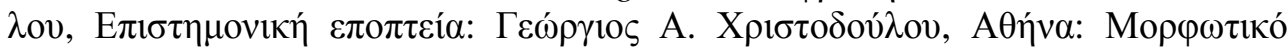

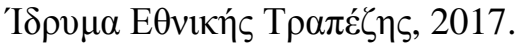

The Greek translation of Stephen Greenblatt's non-fiction novel The Swerve: How

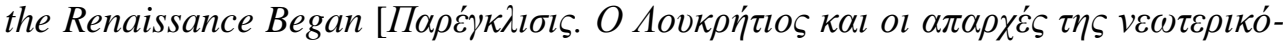
$\tau \eta \tau \alpha \varsigma]$, made by Despoina Kanellopoulou, is praiseworthy because it captures the content, the style and the atmosphere of the original, while it renders it faithfully and vividly. ${ }^{1}$ The translation, produced under the scholarly supervision of Georgios A. Christodoulou, Emeritus Professor of Ancient Greek Philology at the University of Athens, equally competes with the original and fascinates its reader.

Greenblatt has written an academic book that undeniably required a long and copious effort and research, but at the same time it is as enjoyable as a well-written novel. It is not merely a work on the fortune of Lucretius' De rerum natura [On the Nature of Things] and/or its reception - one could easily seek both of these in other academic writings,$-{ }^{2}$ nor does it simply provide some informative details on the

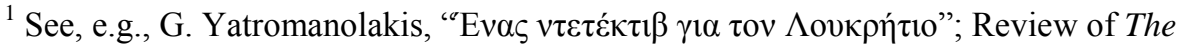
Swerve: How the Renaissance Began (To Vima, 11/03/2018) at http://www.tovima.gr/books-ideas/article/?aid=949724. Date accessed: 24 June 2018. ${ }^{2}$ See, e.g., A. Palmer, Reading Lucretius in the Renaissance. I Tatti studies in Italian Renaissance history, Harvard University Press, Cambridge (MA) - London 2014; D. Norbrook, S. Harrison, P. Hardie (eds), Lucretius and the Early Modern. Classical presences, Oxford University Press, Oxford - New York 2016.
} 
history of classical philology, palaeography and codicology (libraries, book production, manuscript tradition and circulation, etc.) - again there are many excellent books on all these subject matters. Greenblatt's book is all of the above and even more. One could argue that it lacks the scientific details and terminology of philology-oriented academic books on the aforementioned matters. However, it is detailed enough to cover - to some extent - the basic needs of those having a keen interest in philology, in Classical, Medieval and Renaissance studies, in manuscript studies, in the history of book, libraries and art, in the history of scholarship, philosophy, religion and church, and so on. What is more, all these are given in the form of a mesmerizing story that follows its protagonists through an epic journey from the First century BCE to the early Fifteenth century and beyond: the first protagonist is the Florentine humanist and papal secretary Poggio Bracciolini, while the second is Lucretius and his poem De rerum natura.

One could divide the book in three major parts: a) Bracciolini's life, career and humanistic interests, b) The Epicurean philosophy as portrayed in Lucretius' poem, and c) Lucretius' impact on Western thought and civilization. These comprise a rather imbalanced number of chapters, in which one may also find details on the monastic life and scriptoria, the production and quality of parchment, the use of papyrus as a writing material, the destruction of books and libraries, the religious obscurantism of the Middle Ages and the early Renaissance, etc. Although one may regard all these as a medley of sundry details, they all seem to more or less fit in with the entire story.

The story goes back to the winter of 1417 , when Bracciolini is heading to a monastery in central Germany - almost certainly the Benedictine Abbey of Fulda in quest of manuscripts (Chapter One: "The Book Hunter" ["O $\beta 1 \beta \lambda$ io follows his itinerary from Constance, where he had accompanied the Pisan antipope John XXIII for the Council organized there from October 1414, after the latter's deposition that left Bracciolini unemployed. Further to the historical background necessary for the reader to understand the plot of the story, the chapter brightly recreates the early Renaissance conditions (preparations, difficulties, dangers, reactions by the locals, etc.) that itinerants experienced on their trips. After describing older quests for classical manuscripts by Bracciolini and his friend Bartolomeo de Aragazzi, the reader is taken to the former's arrival at the monastery of his destination and shares his excitement at the moment when he discovers the manuscript of Lucretius (Chapter Two: "The Moment of Discovery" ["H $\sigma \tau \imath \mu \mu$ ' $\left.\left.\tau \eta \varsigma \alpha v \alpha \kappa \alpha ́ \lambda v \psi \eta \varsigma^{\prime \prime}\right]\right)$. This chapter also brings to life the silent, yet laborious work of the medieval monastic scriptoria. The author provides a vibrant image of the monastic life and of the rules that compelled monks to acquire and practise reading and writing skills, and how manuscript production ran within this life: from information and details on the parchment and its qualities, the ink and the tools of writing, to the copyists' behaviour and the rules to be followed when in the scriptorium. 
Bracciolini was one of the early Renaissance humanists whose life purpose was the discovery of the books that managed to survive "the teeth of time", and the recovery of the ancient world (Chapter Five: "Birth and Rebirth" ["Г $\alpha v \alpha \gamma \varepsilon \dot{v} \eta\rceil \eta$ "]). Francesco Petrarca was undeniably the first of those early humanists, followed by Giovanni Boccaccio, Coluccio Salutati, Niccolò Niccoli and Bracciolini himself. They all tried to revive the ancient past by searching for and collecting manuscripts of classical authors, collating them and producing reliable texts, and by re-establishing the purity of the Latin language and script, purifying the former from its medieval barbarisms and the latter from its Gothic elements that had penetrated the beautiful Carolingian minuscule script, which Bracciolini and Niccoli turned into the most elegantly executed Humanistic script. Bracciolini's scribal talent and his ambitions guaranteed a position for him in the Papal Curia, a place that despite its religious coverage was full of intrigues and

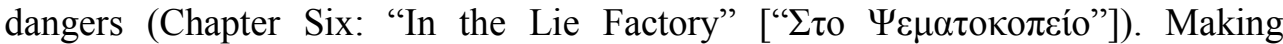
excellent use of the work De curiae commodis [On the Excellence and Dignity of the Roman Court by Lapo da Castiglionchio the Younger, who also sought unsuccessfully - a career in the Papal Curia, Greenblatt marvellously describes the climate of this prestigious, but demanding and fiercely risky employment. Bracciolini himself, though a member of this "lie factory", did not restrain himself from ridiculing certain behaviours in the Curia in his Facetiae [Jocose Tales]. However, the situations were not always jocose, but they comprised venomous attacks between rivals for the same posts, like those between Bracciolini and Lorenzo Valla or George of Trebizond.

If life was perilous for members of the Papal Curia, it was even more hazardous for "the sinister, sly, and ruthless Baldassare Cossa" (p. 241), who called himself Pope John XXIII. The Western Schism that divided the papacy between Rome and Avignon from 1378 was meant to be solved at the Council of Constance, convened by John XXIII in 1414. The author describes all the background preparations and politics before the Council, John's hesitant and long trip along with his Curia from Rome to Constance (Chapter Seven: "A Pit to Catch Foxes" ["Mí $\pi \alpha \gamma i ́ \delta \alpha \gamma 1 \alpha$ $\left.\left.\alpha \lambda \varepsilon \pi \circ \delta^{\prime} \delta \varepsilon \zeta^{\prime}\right]\right)$, the imprisonment, trial and condemnation of the Czech theologian Jan Hus, followed by John's flight from Constance and his deposition, which resulted in Bracciolini's discharge from his post as an apostolic secretary to John, and his quest that led to the discovery of Lucretius' poem.

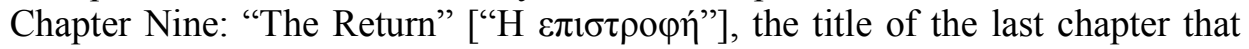
includes information on Bracciolini's life and career, bears a polysemic title: it may refer to his return to Italy from Germany and England, where he spent some time at the service of Henry Beaufort, bishop of Winchester; it may also refer to his return to Florence, where he was elected chancellor of the city, after having served other popes, among whom Eugene IV and Nicholas V; however, the title primarily refers to Bracciolini's request to have his Lucretius returned to him: Bracciolini could not take away with him the manuscript of Lucretius he found in Germany, so he had a copy made for him, which he sent to his friend back home, Niccolò Niccoli. 
Greenblatt presents Bracciolini's attempts at borrowing this copy from Niccoli, who had kept it locked in his library for decades before letting Bracciolini see it again.

The second major part of the book comprises Chapters Three ("In Search of

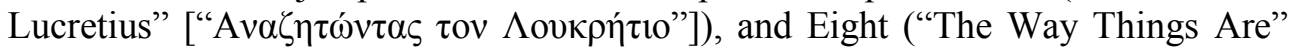

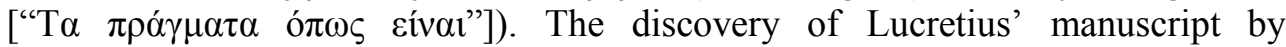
Bracciolini gives Greenblatt the chance for another time travel: this time the story goes back to the First century BCE and the production of Lucretius' poem. Despite the turbulent socio-political conditions of the Roman Late Republic and Early Imperial Period - or on account of these -, and despite the predominance of Stoicism, Epicureanism thrived among the Roman elites, who found in Lucretius' poem the epitome of this philosophical system, as expressed by its founder almost two centuries earlier. The discovery of some parts of Lucretius' poem in some papyrus rolls from the Villa of the Papyri at Herculaneum in the Eighteenth century provides Greenblatt with sound arguments about the reception of the Roman poet by his contemporaries, but also with the opportunity to talk about the production and trade of papyrus as a writing material. He also finds the chance to hint on the content of Lucretius' text within the Epicurean philosophy and to trace back the fate of some of the public and private libraries of the time, an issue expanded in

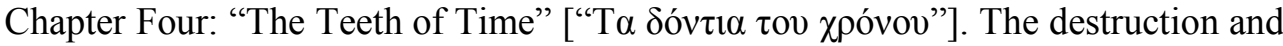
loss of books and libraries and the various problems in the manuscript tradition of works from the classical Antiquity are the main points of this chapter, which takes its title from the characterization of the bookworm as "one of the teeth of time", according to Robert Hooke (p. 134). Related to this is Greenblatt's discussion of the destruction of the Library of Alexandria (and the murder of Hypatia) as a result of ideological and religious conflicts, a victim of which was Lucretius too.

What Greenblatt just hinted in Chapter Three about Lucretius' De rerum natura in relation to the Epicurean philosophy, he expands in detail in Chapter Eight. He presents the major principles of Epicureanism as appear in Lucretius' poem: "Everything is made of invisible particles ... The elementary particles of matter 'the seeds of the things' - are eternal ... The universe has no creator or designer ... Everything comes into being as a result of a swerve [where the term $\pi \alpha \rho \varepsilon \dot{\gamma} \gamma \lambda \imath \sigma l \varsigma$, in Lucretius' text: declinatio, inclinatio, or clinamen appears] ... Everything comes into being as a result of a swerve ...", and so on. Briefly, Lucretius (and Epicurus) believed in a god-free world, not created by divine power and providence, but composed of atoms, minuscule invisible particles that move eternally and act unpredictably. The swerve $\left[\pi \alpha \rho \varepsilon^{\gamma} \gamma \kappa \lambda l \sigma l \varsigma\right]$, the deviation of the atoms from a direct course makes them collide against each other and create various forms of life. However, these formations are not everlasting, and the atoms, following the forces of the universe, break free, disseminate and move on in their course, which means the end of life. So, according to this theory, human beings (and their souls) created by a similar assemblage of atoms - should not fear death, because there is no afterlife as described, professed or promised by religions. For the time when 
they live, pleasure [ $\eta \delta o v \eta \dot{\eta}=$ freedom from fear and pain] should be their only life purpose. These principles are analysed sufficiently enough to provide the reader with an essential knowledge of Epicurus' philosophical ideas. The chapter closes with his reference to Sandro Botticelli's famous painting La Primavera (The Spring), inspired by Lucretius' description of the earth's rebirth in his poem (5.737-740).

The third major part of the book (Chapter Ten: "Swerves" ["П

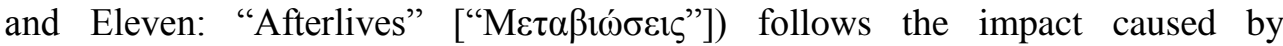
Lucretius' poem on European thought and civilization after its discovery by Bracciolini. From the reproduction of the manuscript text by Niccolò Machiavelli, and Lorenzo Valla's De voluptate (On pleasure) to the editions of De rerum natura (all with precautionary notes on its content due to religious restrictions), from Thomas More's Utopia to Giordano Bruno's writings and his condemnation to death, from Michel de Montaigne to William Shakespeare, from Galileo Galilei to Molière, from Lucy Hutchinson's English translation to Isaac Newton and Thomas Jefferson. The academic basis, approach and analysis of some of the content of these chapters intertwine with miscellaneous details that weaken the former. However, one should not forget that this is a non-fiction novel, which despite its scholarly part must fulfil its literary purposes, too.

The book is accompanied by copious notes (pp. 407-473), selected bibliography (pp. 479-514), an index (pp. 517-537) compiled by Chaido Papavasiliou, and twelve images. The notes and the bibliography in the Greek edition have been enriched and augmented by Georgios A. Christodoulou, who also reviewed the translation of all the non-English quotations (Latin, Ancient Greek, French, and Italian) in the text and the notes.

The book offers an easily accessible principal knowledge on many aspects of the Classical and other studies, as they were described in the opening part of this review. Although it is an academic book, however, it cannot substitute for purely academic, subject-matter works; it may as well be read selectively and complementarily along with other more scholarly, more specialised and more detailed works. Without disregarding the significance of Lucretius and his poem in changing or shaping the Western thought and culture, one needs to be careful in attributing this change to this poem alone: the author's claim that Lucretius caused an intellectual and cultural revolution that initiated the Renaissance is rather exaggerated and overvalued. As a cultural and intellectual movement that liberated people from the medieval obscurantism, ignorance and hostility to everything nonChristian or non-religious - something that also needs discussion, which cannot be carried out here and is out of the scope of this review -, the Renaissance was the result of many and various factors. The discovery of classical Greek and Latin authors and texts and the partial recovery of the ancient world was only one of these factors. Lucretius just happened to be one of the authors discovered; the content of his poem was certainly radical - the "swerve" from the mainstream, religion-controlled-and-oriented life (cf. p. 25) - when its manuscript was 
discovered by Bracciolini, but it cannot be supported that it was the text from which the Renaissance and modern world originated and which formed the Western European civilisation from the Sixteenth century onwards.

Despite its minor or major deficiencies and weaknesses, ${ }^{3}$ Greenblatt's book offers a wonderful insight into the amazing world of the Renaissance and its people; it is superbly readable and entertaining; it is unquestionably significant for the theory and the epistemology of the Classical Studies in a popular and enjoyable version.

${ }^{3}$ See, e.g., J. Monfasani, Review of The Swerve: How the Renaissance Began (Reviews in History, 05/07/2012, review no. 1283) at http://www.history.ac.uk/reviews/review/1283. Date accessed: 24 June 2018. 
TO ПЕPIO $\triangle$ IKO

«EPISTēMēS METRON LOGOS»

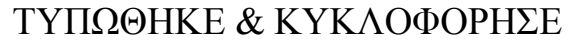

TON OKT $\Omega$ BPIO TOY 2018 